\title{
改良土とジオグリッドを組み合わせた 補強土壁の遠心振動台実験
}

\author{
斉藤知哉 1 - 伊藤秀行 $2 \cdot$ 桑野二郎 $3 \cdot$ 井沢 淳 4
}

\begin{abstract}
筆者らは、補強土壁の壁面部分（パネル背面から設計により決まる範囲）に改良土を配置し、ジオグリッド と組み合わせる新しいタイプの補強土工法の開発を進めてきたが、耐震性能に関しては未解明な部分が多く課 題となっていた。そこで、本工法の地震時举動（変形特性）を把握することを目的として、遠心模型振動実験 を行った。その結果、改良土のみ配置したケースでは改良土にクラックが発生し、ジオグリッドのみでは変形 が大きい結果となった。これに対し改良土とジオグリッドを組み合わせた場合は变形が小さく抑えられ高い安 定性を示した。また大きな地震動を加えた場合、改良土にクラックが発生する恐れがあるが、短繊維を混合す ることにより抑制され、短絒維混合は耐震性能を向上させるのに有効な手段となることが明らかとなった。
\end{abstract}

キーワード : 改良土, ジオグリッド, 短繊維, 遠心実験, 振動台実験

\section{1. はじめに}

補強土工法は、ジオグリッドを用いた工法をはじめと して、さまざまな工法が開発されている。特にジオグリ ッドを用いた補強土工法は、地震時の挙動が良好で、大 規模地震に対しても崩壊に至らず、若千の変形のみに抑 えられるという報告 ${ }^{1}$ がなされている。筆者らも、補 強土壁の壁面部分に改良土を配置して、ジオグリッドと 組み合わせて、変形の少ない安定した盛土を構筑できる 新しいタイプの補強土工法の開発を進めてきた ${ }^{2)}$ 3)。 本工法の概念図を図ー 1 に示卞。本工法の特長としては、 以下の点が挙げられる。

・改良土の強度を補強土の設計に取り入れる

・改良土の効果によりジオグリッドの使用量が減る

・盛土材は砂質土に限定されず、現地発生土を有効利 用できる

・ パネルとジオグリッドは連結されず、ジオグリッド は改良土中に定着させる。

・改良土には短䋐維を混合し、じん性や対浸食性、而付 震性の向上を図る

開発に当たっては、短繊維を混合した改良土の強度 特性や改良土中のジオグリッドの引抜き実験 ${ }^{2)}$ などの 要素に関する実験、また模型載荷試験や現場施工実験 3) などを進めるとともに、設計法の構築も行い、工法 の確立を行ってきたが、耐震性能に関しては未だ未解明

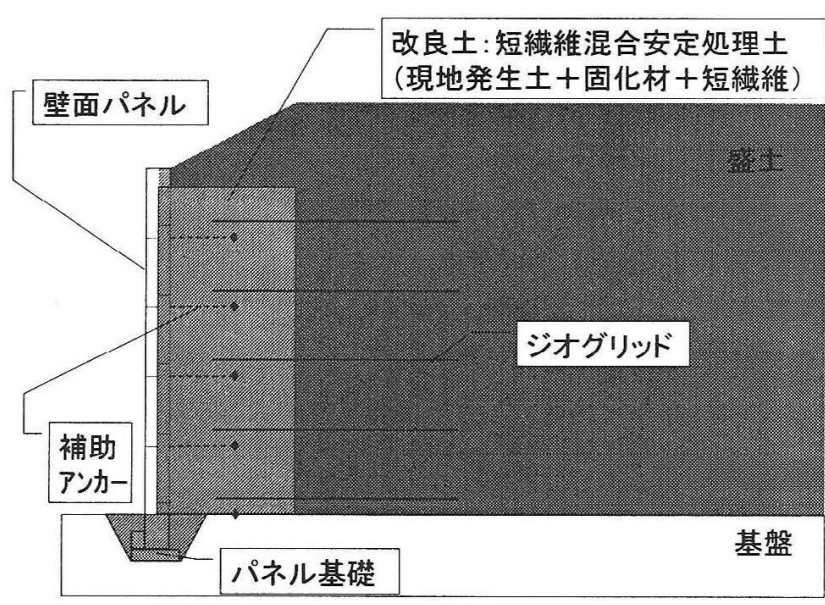

図-1 概念図

な部分が多く課題となっていた。そこで本稿では、改良 土とジオグリッドを組み合わせた補強士壁の地震時挙動

(変形特性) を把握し、本工法の耐震性能の確認と耐震 設計法の検証を行うことを目的として、改良土とジオグ リッドを組み合わせた補強土壁の遠心模型振動台実験を 行った。その結果、改良土とジオグリッドを組み合わせ た補強土壁は、地震時においても変形が少なく安定した 補強十壁であることが確認できたので、本実験結果につ いて報告することとした。

\footnotetext{
1正会員，大日本土木㑣技術研究所 開発技術部，主任研究員（广350-1331 埼玉県狭山市新狭山1-1-1）

2正会員, 大日本土木森技術研究所 開発技術部, 主任研究員（同上

3正会員, 東京工業大学大学院理工学研究科土木工学専攻, 助教授（テ152-8552 目黒区大岡山12-12-1 緑が丘1号館）

4正会員, 東京工業大学大学院理工学研究科土木工学専攻, 助手

II

5 号館)
} 


\section{2. 実験概要}

\section{(1)模型地盤}

振動台実験は 50G の遠心加速場にて行った。模型地 盤は、内寸幅 $430 \mathrm{~mm}$ 、深さ $250 \mathrm{~mm}$ 、奥行き $150 \mathrm{~mm}$ の剛性 容器内に盛土高さ $200 \mathrm{rm}$ （実物換算で $10 \mathrm{~m}$ ） となるよう 作製した。盛土の形状および設置した計測機器の位置 を図一2に示す。

実験材料として用いた材料の主な物性值を表一 1 に 示す。盛土材料には豊浦砂（Dr=80\%）を用いた。改良 土は、一軸圧縮強度が $\mathrm{q}_{\mathrm{u}}=420 \mathrm{kN} / \mathrm{m}^{2}$ となるよう、含水比 を $10 \%$ に調整した豊浦砂に高炬セメント $\left(60 \mathrm{~kg} / \mathrm{m}^{3}\right)$ を 混合し、湿潤密度を $\gamma_{\mathrm{t}}=1.6 \mathrm{~g} / \mathrm{cm}^{3}$ で作製し、7 日間養生 した。短纎維は、実際に現場で使用している材料であ るビニロン短緘維(太さ $\phi=43 \mu \mathrm{m}$ )を約 $10 \mathrm{~mm}$ にカット

（現場使用時の長さは $30 \mathrm{~mm}$ ) して改良土に混合した。 模型ジオグリッドは、実際に使用するグリッドと引張剛 性をあわせており、厚さ $1 \mathrm{~mm}$ のポリカーボネイト板を用 い、図ーーに示すように、円中心間隔 $15 \mathrm{~mm}$ ピッチで $\phi$ $=10 \mathrm{~mm}$ の穴を開けたものを使用した。また模型ジオグリ ッドの引き抜き試験を行い、豊浦砂との引き抜き強度の 確認を行った。その結果（引き抜き量と引き抜きせん断 応力の関係、上載圧と引き抜き強度の関係）を図一 4 に 示す。また模型壁面パネルには、実際に使用するコンク リートパネルの重量を考慮して厚み $5 \mathrm{~mm}$ のアルミ板を用 いた。

模型地盤の作製方法を以下に示す。

(1) 改良土部分の作製

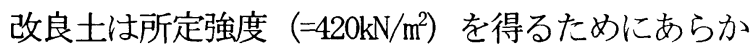
じめ作製し、7 日間養生する。改良土の混合は、ビ ニール袋に標準砂とセメントを入れ振とうし、さら に水を加えて十分混合するまで振とうする。そして、 短䋊維を所定量計量し、束にならないよう注意しな がら混合する。土槽内への改良土の作製は、前面側 にパネルを設置して盛士側には所定の幅になるよう 型枠を設置する。そして、改良土は高さ $1 \mathrm{~cm}$ ごとに所 定の密度となるよう突き固め、所定の位置にジオグ リッドを敷設しながら、模型高さ $20 \mathrm{~cm}$ まで繰り返し て作製する。写真一 1 に改良土作製後の状況を示す。

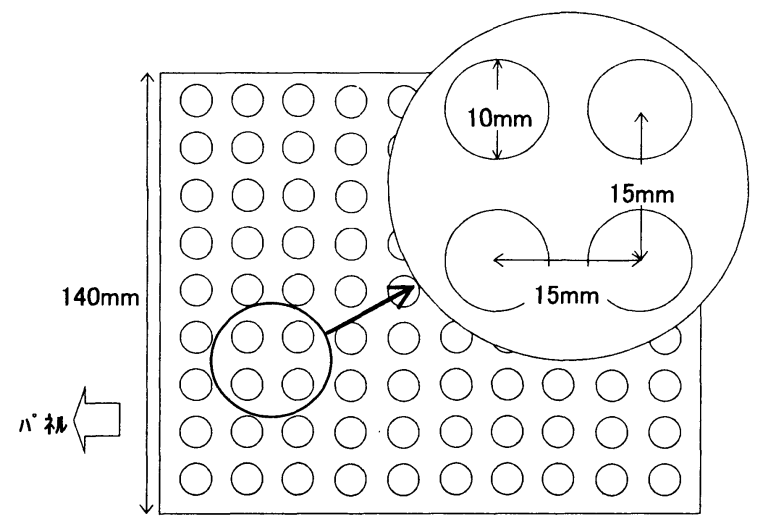

図ー3 模型ジオグリッド

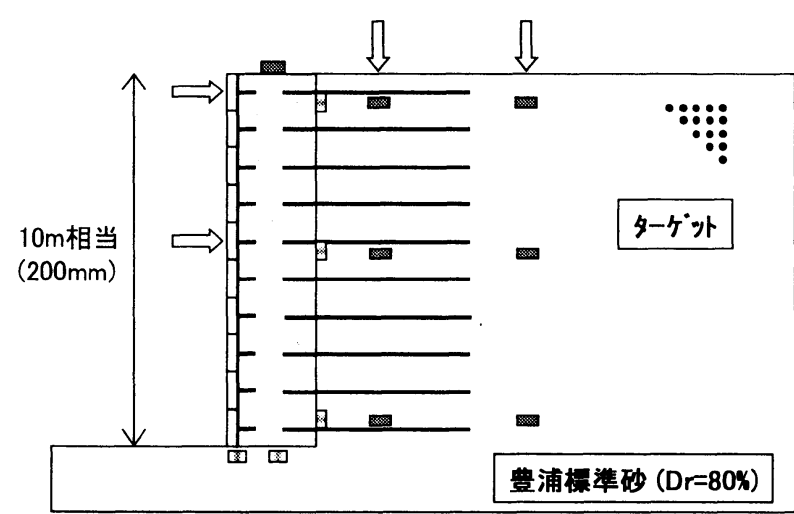

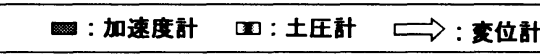
図一2 模型盛土地盤および計測機器配置

\begin{tabular}{|c|c|}
\hline \multicolumn{2}{|r|}{ 表一 1 材料物性 } \\
\hline 盛土 & 豊浦砂 $\operatorname{Dr}=80 \%\left(\phi=42^{\circ}\right)$ \\
\hline 改良土 & $\begin{array}{c}\text { 豊浦砂 } \omega=10 \% \\
r \mathrm{t}=1.600 \mathrm{~g} / \mathrm{m}^{3} \\
\text { 高炉也x次 } 60 \mathrm{~kg} / \mathrm{m}^{3} \\
\text { qu }=420 \mathrm{kPa} \text { (7days) }\end{array}$ \\
\hline 短織維 & $\begin{array}{c}\text { ビ こロ (実物と同様) } \\
\text { 長さ } \mathrm{L}=10 \mathrm{~mm} \\
\text { 太さ } \phi=43 \mu \mathrm{m}\end{array}$ \\
\hline ジオグリッド & $\begin{array}{l}\text { 术师-ボ } ネ \text { ネト(polycarbonate) } \\
\text { 引張強度 : } 391.3 \mathrm{kN} / \mathrm{m} \\
\text { 豊浦砂との摩擦角 : } 42.4^{\circ}\end{array}$ \\
\hline パネル & アルミ(厚み $5 \mathrm{~mm})$ \\
\hline
\end{tabular}
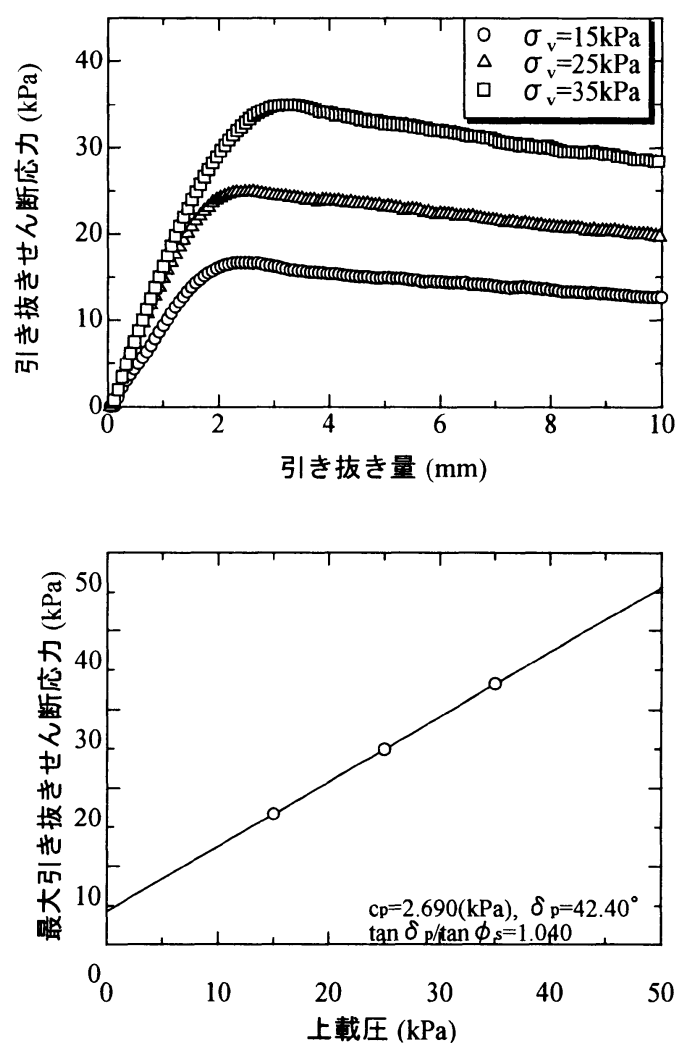

図ー4＼cjkstart模型ジオグリッドの引き抜き実験結果 
(2) 盛土部分の作製

写真一 2 に盛上作製状況を示す。模型地盤悩実験 前日に作製する。まずガラス面上に変形観测用の夕 ーグットを並べ、その後、土槽の側面を上にして側 面板を取り外し、盖生 6 日目の改良土を設置して盛土 形状の型枠を入れる。盛土は標準砂を空中落下法に より相対密度 $80 \%$ となるよう側面から作製する。この とき計測機器を所定の位置に設置する。盛土を均し た後、側面板を取り付け、土槽を元の状態に戻し、 型枠を取り除いた後、盛土上部を整形して盛土地盤 を完成させる。

\section{(2) 実験ケース}

表一2、図一5に実験ケースを示す。Case1 (GG) はジオグリッドのみで安定するケース、Case2（NW） は改良土のみで盛土が安定に構築できる最小改良土幅と したケース、Case3（WW）は改良土のみで設計水平震 度 0.2 を考虑した改良土幅としたケ一ス、Case4（H F)、Case5（H S H）、Case6（H S）は改良土とジオ グリッドを組み合わせたケースで、Case4 は改良土に短 繊維混合なし、Case5 は短緎維混合 $0.05 \%$ （重量百分 率)、Case6 は短繊維混合 $0.1 \%$ 、計6 ケースについて 行った。

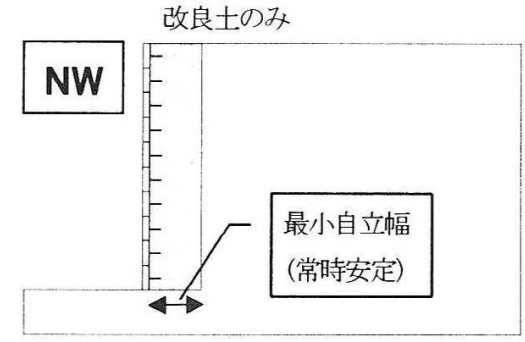

Case.2

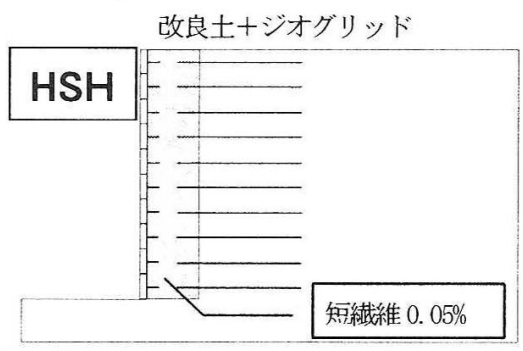

Case.5

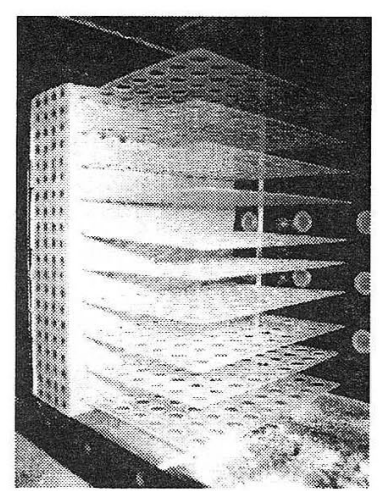

写真 -1 改良土作製後

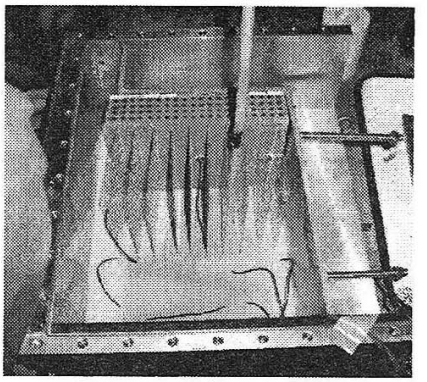

写真一－2 盛土作製状況

\begin{tabular}{|c|c|c|c|c|c|}
\hline \multirow{3}{*}{\multicolumn{2}{|c|}{ Case }} & \multicolumn{2}{|c|}{ 改良土 } & \multicolumn{2}{|c|}{ ジオグリッド } \\
\hline & & & & & \\
\hline & & \multirow{2}{*}{$\begin{array}{c}\text { 改良土幅 } \\
- \\
\end{array}$} & \multirow{2}{*}{$\frac{\text { 短繊維 }}{-}$} & \multirow{2}{*}{$\begin{array}{c}\text { 敷設長 } \\
120 \mathrm{~nm} \\
\end{array}$} & \multirow{2}{*}{$\begin{array}{c}\text { 敷設数 } \\
10\end{array}$} \\
\hline 1 & GG & & & & \\
\hline 2 & $\mathrm{NW}$ & $42 \mathrm{~nm}$ & $0.00 \%$ & - & - \\
\hline 3 & WW & $80 \mathrm{~mm}$ & $0.00 \%$ & - & - \\
\hline 4 & $\mathrm{HF}$ & $42 \mathrm{~mm}$ & $0.00 \%$ & $100 \mathrm{~nm}$ & 10 \\
\hline 5 & $\mathrm{HSH}$ & $42 \mathrm{~mm}$ & $0.05 \%$ & $100 \mathrm{~nm}$ & 10 \\
\hline 6 & HS & $42 \mathrm{~nm}$ & $0.10 \%$ & $100 \mathrm{~nm}$ & 10 \\
\hline
\end{tabular}

Case. 1

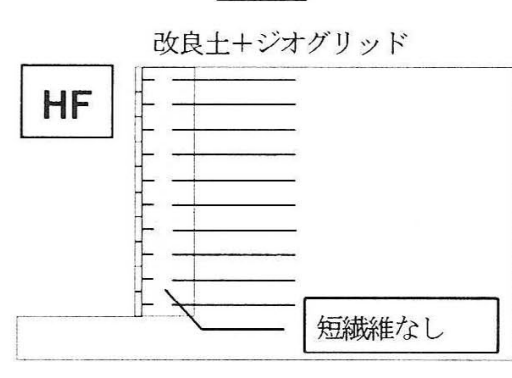

Case. 4

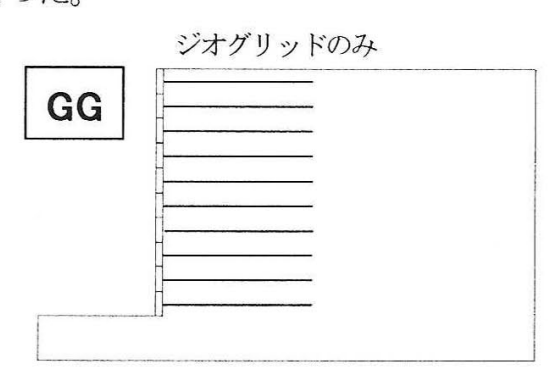

\section{(3) 計測項目}

計測は、図ー2に示したように、パネル下および改良 土下の鉛直土压を 2 点、改良土 (Case1 はパネル) の水 平土圧を 3 点計測した。また、応答加速度はジオグリッ ド敷設範囲内に 3 点、盛土内に 3 点、改良土上（地表 面）に 1 点の計 7 点計測し、入力加速度は 1 点（土槽に 設置）計測した。変位は、パネルの水平変位を 2 点、盛 土の沈下量を 2 点計測した。また、地盤の変形を観察す るのに、CCDカメラを用いた画像処理システム ${ }^{4)}$ 5) を用い、地盤内に埋設したターゲット位置を計測した。

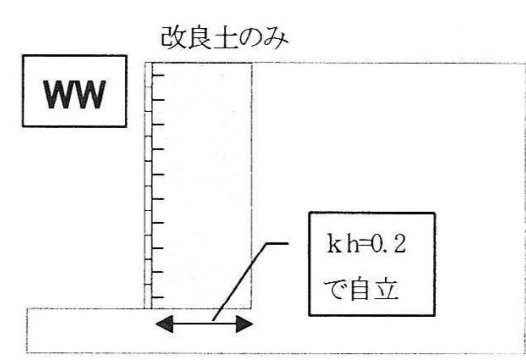

Case. 3

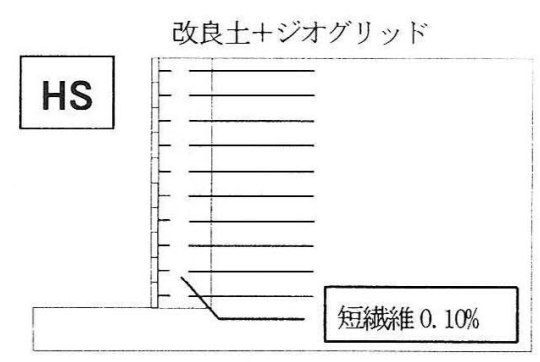

$\underline{\text { Case. } 6}$

図一 5 実験ケース

\section{(4) 実験方法}

実験は東京工業大学にある遠心振動台実験装置6) を 用いて行った。振動台実験は、遠心加速度を50Gまで上 げ、盛土の状態が安定した後、表ー3に示寸ように、周 波数 $100 \mathrm{~Hz}$ (実物換算 $2 \mathrm{~Hz}$ ）の正弦波を入力した。step1〜 3 までは、振幅をそれぞれ、0.3、0.6、1.0 omm と増幅させ、 20波づつ入力した。Step4以降は、40波、振幅 $1.0 \mathrm{~mm}$ とし て破壊が生じるまでこの条件で加振し続けた。図一6に Case3の入力加速度時刻歴を示す。 
表一3 入力 Step と入力波の条件

\begin{tabular}{llll}
\hline & 振幅 & 入力波数 & 周波数 \\
\hline $1^{\text {st }}$ & $0.3 \mathrm{~mm}$ & 20 & $100 \mathrm{~Hz}$ \\
\hline $2^{\text {nd }}$ & $0.6 \mathrm{~mm}$ & 20 & $100 \mathrm{~Hz}$ \\
\hline $3^{\text {rd }}$ & $1.0 \mathrm{~mm}$ & 20 & $100 \mathrm{~Hz}$ \\
\hline $4^{\text {th }}$ & $1.0 \mathrm{~mm}$ & 40 & $100 \mathrm{~Hz}$ \\
\hline $5^{\text {th }}$ & $4^{\text {th }}$ の条件と同様 & \\
$\sim$ & \multicolumn{3}{l}{} \\
\hline
\end{tabular}

\section{入力波形：sin 波 遠心加速度 : 50g}

\section{3. 実験結果}

\section{（1）静的状態（遠心加速度 50G 増加完了時）}

遠心加速度を50Gまで上げたときの、各ケースの応力 （土圧）状態および変形（壁面水平変位、盛土沈下量） 状態を図ー7に示す。ただし、改良土とジオグリッドを 組み合わせたCase4〜6は、同様な傾向を示したので Case6のみの表示とした。また計測結果は遠心場での值 をそのまま用いることとした。

a) 土圧

図一 7 (c)の点線は試行くさび法より求めた土圧を理 論值として、(d) はジオグリッド敷設範囲までを仮想擁 壁としたときの地盤反力分布を理論值として示寸。水平 土圧に関しては、ジオグリッドのみのCase1が若干大き いものの、理論值より小さい值が計測された。また鉛直 土压も、理論值より小さく、特につま先部分（パネル 下）のほうはかなり小さい值が計測された。

b) 変位

盛土の沈下量を見ると、改良土部分ではほとんど沈 下していない。一方、盛土では全体的に約 $1 \mathrm{~mm}$ の沈下が 見られる。壁面変位は、どのケースもほとんど変位がな く最大で $1 \mathrm{~mm}$ 程度、盛土高さ $(\mathrm{H}=200 \mathrm{~nm})$ に対して0.5\%程 度である。遠心加速度 $50 G$ 上げ後は、どのケースにおい ても、転倒などの崩壊もなく、また応力集中や大きな変 形も認められないことから、振動台実験前の静的状態は 安定した状態であったことが確認された。

\section{(2) 振動台実験}

\section{a) 変形}

図一8に各ケースの振動台実験最終形状とその時の写 真を示す。ジオグリッドのみの Casel では、加振は Step4 までであったため、明確な破壊は認められなかっ たが、壁面の中腹がはらみ出すような変形形態となり、 補強領域以降（ジオグリッド敷設範囲以降）の沈下が大 きい結果となった。幅狭改良土のみの Case2 では、盛土 を安定に構筑できる最小改良土幅であるため、最初の加 振により改良土のつま先を中心に転倒する変形形態とな り、Step2 において写真のように下部からクラックが発

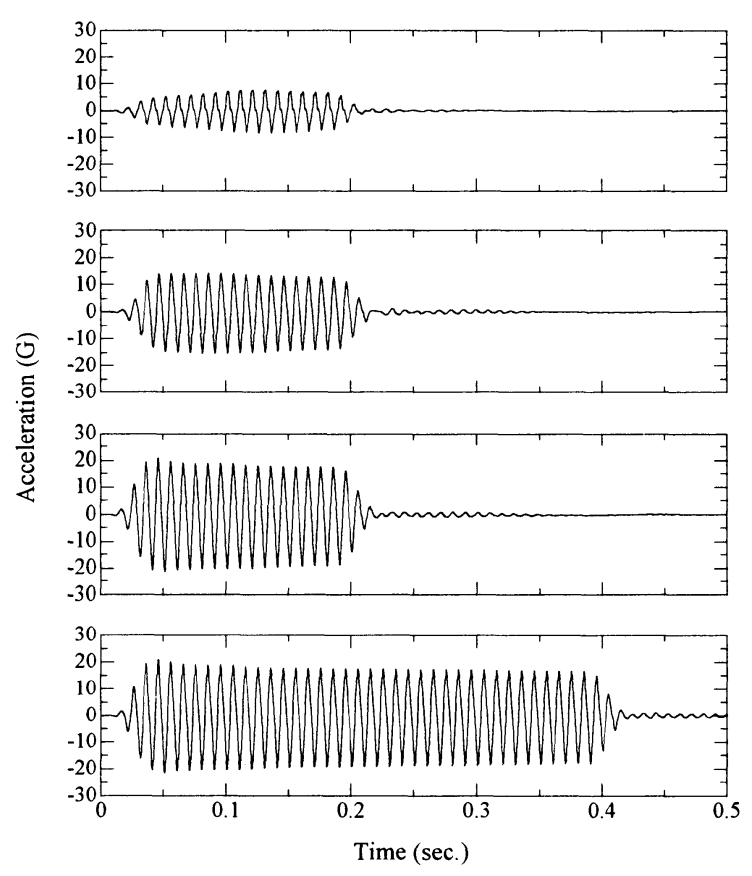

図－6 入力加速度時刻歴 (Case3)

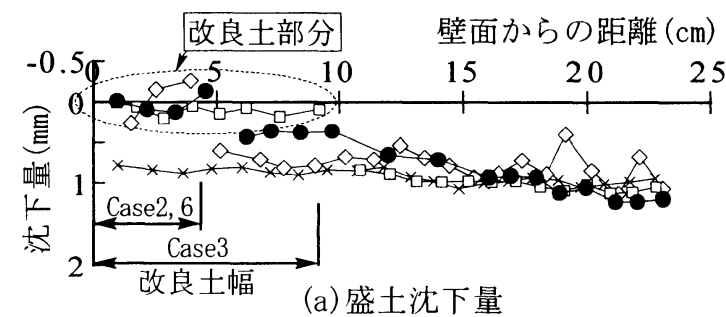

壁面変位量 $(\mathrm{mm})$ 改良土orパ礼に作用寸る土圧

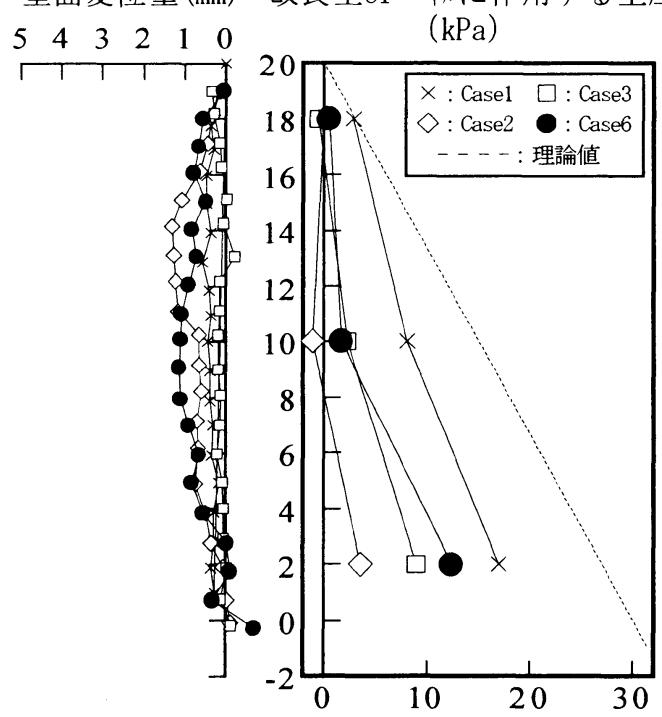

(b) 壁面変位量

(c) 水平土圧

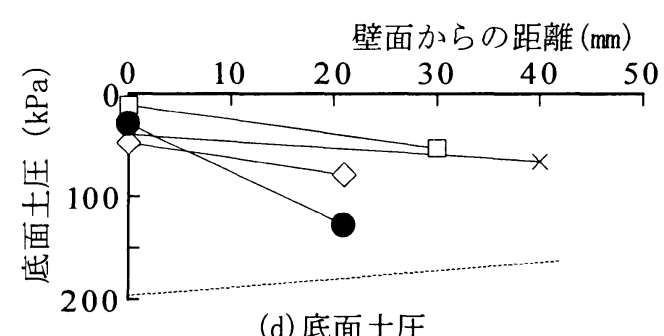

図-7 遠心加速度 50G 増加後の静的状態 
生して完全に転倒崩壊した。幅広改良土のみ の Case3 では、Case2 と同様に加振により改良 土のつま先を中心に転倒子る変形形態となり、 加振 Step3 において改良上つま先で応力が集 中し、そこから改良土内右上方に向かってク ラックが発生した。短緎維混合なしの改良土 とジオグリッドを組み合わせた Case4 では、 Step1, 2 では変形がほとんど見られなかったが、 Step3において改良土に縦にクラックが発生し た。これは改良土にかかる地震時の自重慣性 力に対して、ジオグリッドの引き留め効果が 発揮される。ここで改良土内に引張り力が発 生し、改良土が引張り破壞を生じたと考えら れる。一方、短繊維混合 $0.05 \%$ の改良土とジオ グリッドを組み合わせた Case5 では、 Step1, 2, 3 では変形がほとんど見られない結果 となったが、Step4 において Case4 と同様に改 良土に縦にクラックが発生した。また短繊維 混合 $0.1 \%$ 改良上とジオグリッドを組み合わ せたCase6 では、当初予定していた Step4 まで は変形もほとんど見られない結果となった。 そのため破壊するまで加振したところ、Step6 において Case4, 5 と同样に改良土中央に縦ク ラックが発生した。このことから改良土に発 生するクラックを抑制するのに短繊維の混合 が大きく寄与していることが確認された。

\section{b) 加速度パワー〜変位}

図ー9に各ケースの各ステップにおける最 大人力加速度の計測値を示す。加振装置は変 位制御であるため、各 Step において入力加速 度がバラついた。特に Case1, 2 の入力加速度 が小さかったことがわかる。そのため、各ス テップの最大入力加速度で各ケースの比較を することは難しいことから、式(1)で求められ る加速度パワー $\mathrm{I}_{\mathrm{E}}$ を指標として、これと壁面 水平変位の関係をまとめ、各ケースを比較す ることとした。

$$
I_{E}=\int_{0}^{T} a^{2} d t \quad \text { 式(1) }
$$

a: 入力加速度

$\mathrm{T}:$ 地震動の記録辰

図ー 10 に加速度パワーと壁面变位の関係を 示す。兵庫県南部地震相当の $\mathrm{I}_{\mathrm{E}}(=0.521 \times$ $\left.10^{6}\left[\mathrm{~cm}^{2} / \mathrm{s}^{3}\right]\right)$ において比較すると、ジオグリッ ドのみのCase1または改良土のみのCase2, 3に比 心゙、改良土とジオグリッドを組み合わせた Case4, 5, 6では、変位量は半分以下と小さい。 また釧路沖地震相当の $\mathrm{I}_{\mathrm{E}}\left(=2.26 \times 10^{6}\left[\mathrm{~cm}^{2} / \mathrm{s}^{3}\right]\right)$
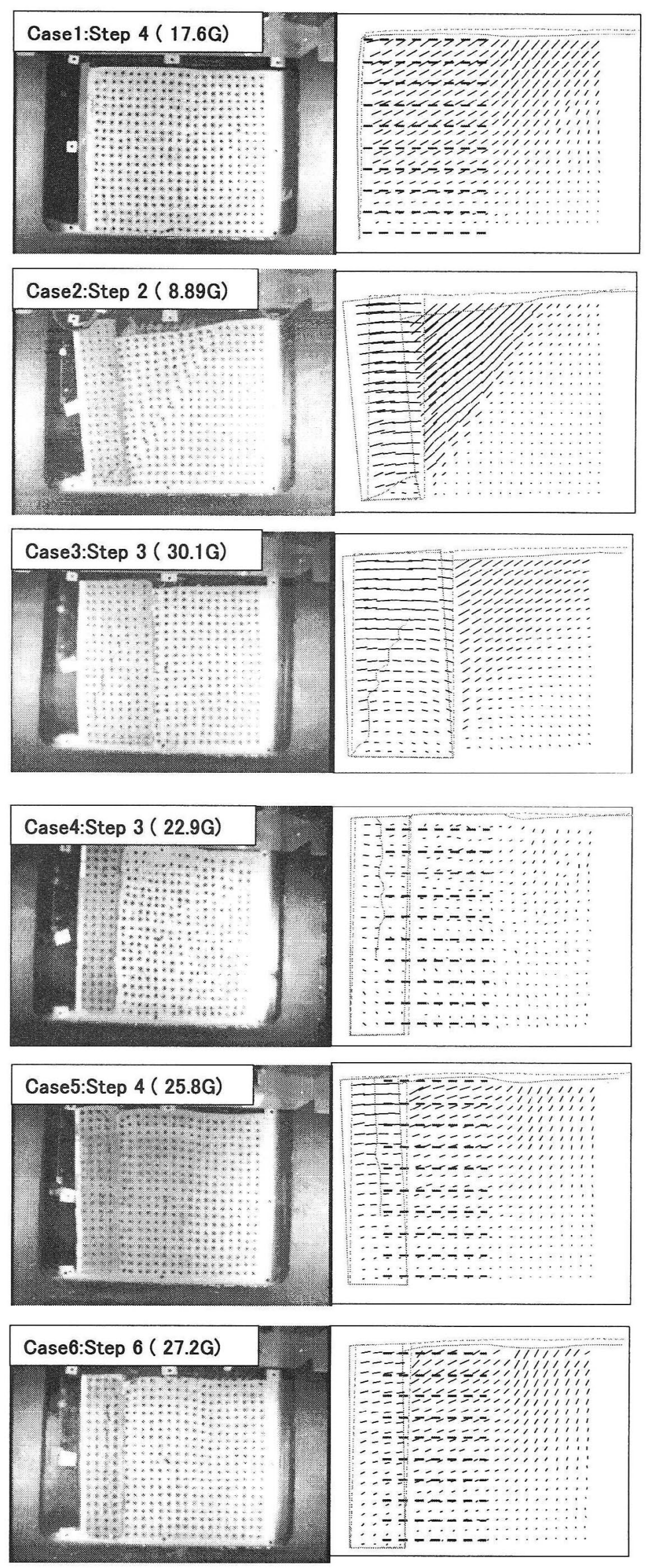

図ー8 振動台実験最終時の写真と変位ベクトル図 


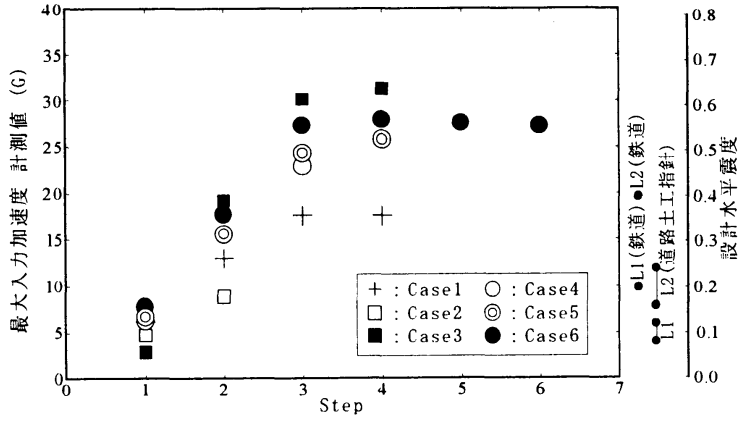

図-9 最大加速度

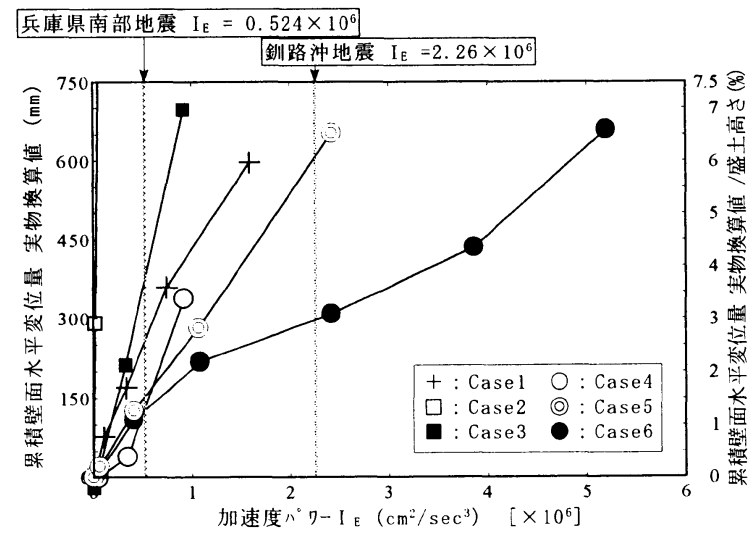

図一-10 壁面変位と加速度パワー
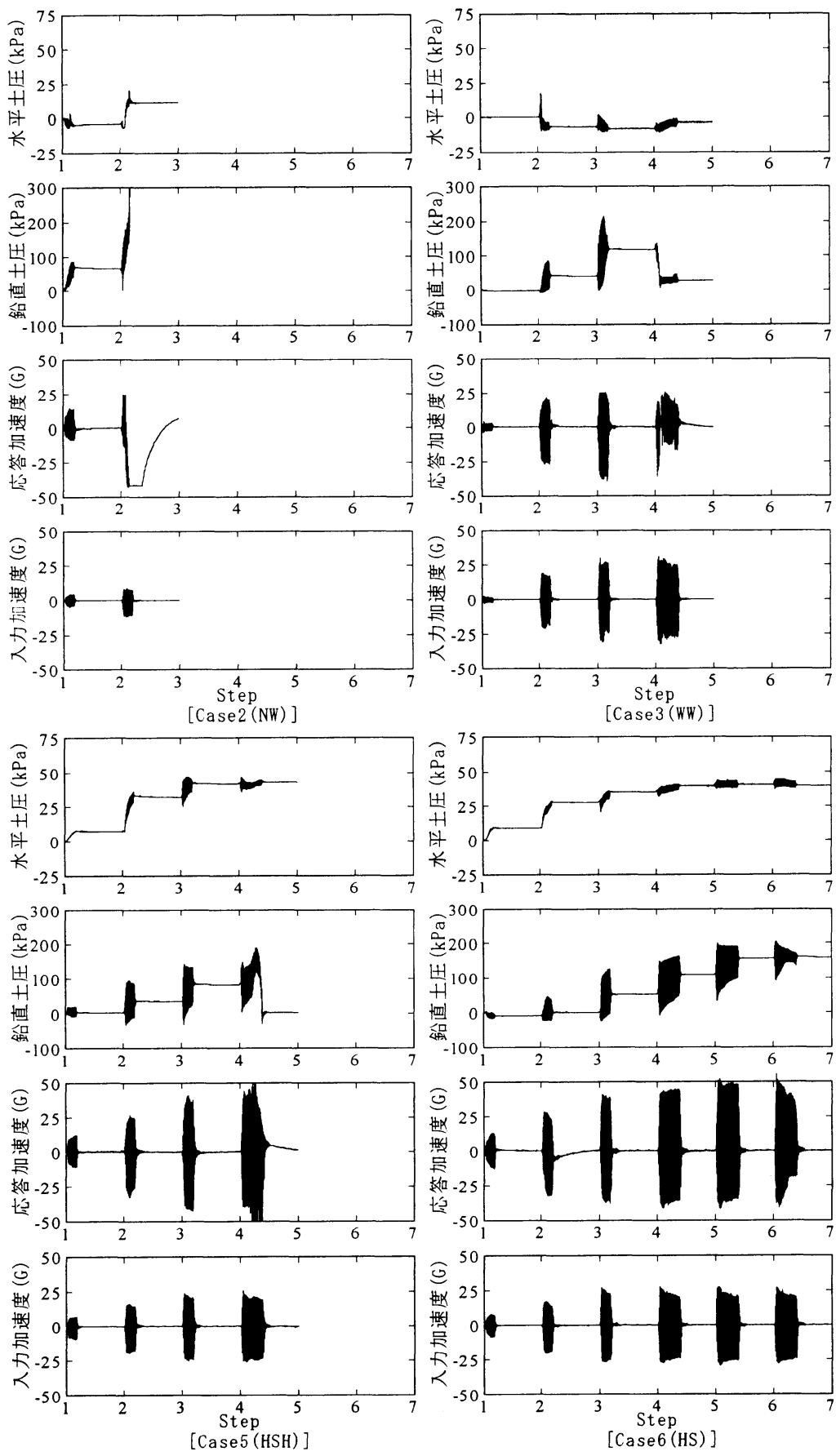

図一 11 計測結果（土圧計、加速度計） 
付近においては、短絨維混合した改良土とジオグリッド を組み合わせたCase5, 6以外では、そこまでに破壊もし くは大きな変形を起こす結果となっており、短䋐維混合 した改良土とジオグリッドを組み合わせた補強土壁は、 レベル II地震動に対しても変形を小さく抑えられ、安定 した補強土壁であることが確認できた。

\section{c) 土压}

図ー 11 に土圧と入力および応答加速度の計測結果を 示す。なお、計測結果は振動実験前をイニシャル值とし、 水平土圧は改良土もしくはパネルの最下段（高さ $2 \mathrm{~cm}$ ) にかかる水平土圧、鉛直土圧はパネル直下にかかる鉛直 土圧の計測結果を示す。Case1では、加振Stepによって 鉛直土圧は変化ないものの、パネルにかかる水平土圧は 加振とともに累積して大きくなっていくことがわかる。 Case2ではStep2で転倒崩壊したため、鉛直土圧は急増し、 改良土つま先で応力集中していることがわかる。Case3 においてもCase2 と同様で加振により改良土つま先で応 力集中し、鉛直土圧は、Step3で改良土にクラックが発 生するまでは上昇するが、Step4で崩壊するとともに減 少している。Case4, 5, 60改良土とジオグリッドを組み 合わせたケースでは、Step2までは鈆直土圧の上昇はほ とんど見られず、改良土は転倒せず変形もほとんどして いなかったが、さらに加振を続けることにより徐々に鉛 直土圧は増していることがわかる。

図-12 にCase6の改良土下つま先部分の土圧と中央 部分の土圧を示す。また、図一 13 に改良土の回転角之 改良土下にかかる鉛直土圧の関係を示す。なお、改良土 つま先下の土圧を実線で、改良土中央下の土圧を破線で 示す。つま先部分の土圧は、加振によってCase6では Step2まではほとんど増加せず、その後徐々に増加して いっている。一方、中央部下の土圧は加振とともに増加 LStep3でピークを迎え、その後は徐々に減少している。 土圧の計測結果からも、改良土が転倒回転しつつあるこ とが確認できる。また改良土幅が同じであるCase2 (৩) とCase6（○）のつま先部分にかかる土圧を比べ ると、回転角に対し、ほぼ同值の土圧がかかっており、 ジオグリッドは改良土の転倒を引き留め、回転角を抑え るものの、同回転角であればつま先にかかる土圧は変わ らないことがわかった。

\section{d) 応答加速度}

図-14に入力加速度に対寸る改良土上の加速度応 答倍率を示寸。ジオグリッドのみは、ジオグリッド敷設 内での応答加速度ではあるが、ほぼ 2 倍の増幅が見られ た。改良土のみでは、Case2 では約 3 倍増幅し、壁面の 変形量も大きかった。一方 Case3 では剛な塊（改良土） が幅広くあるため、増幅せず入力と同程度の值が計測さ れた。やや剛な改良土と柔なジオグリッドの組み合わせ では、1.5〜2 倍の増幅が見られた。
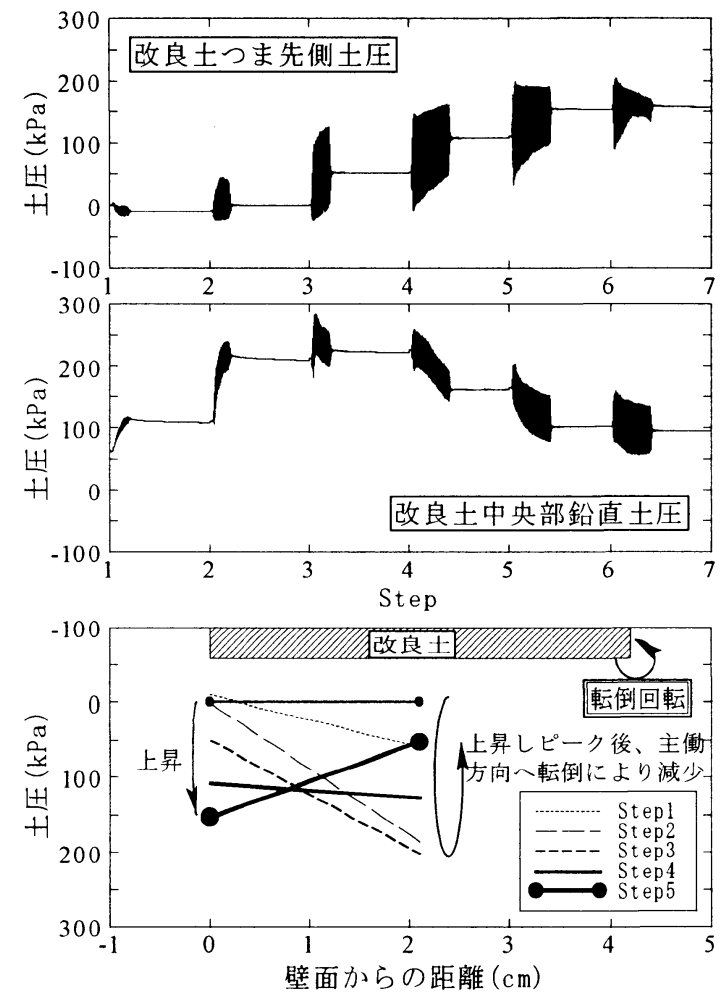

図-12 土圧計測結果 (Case6)

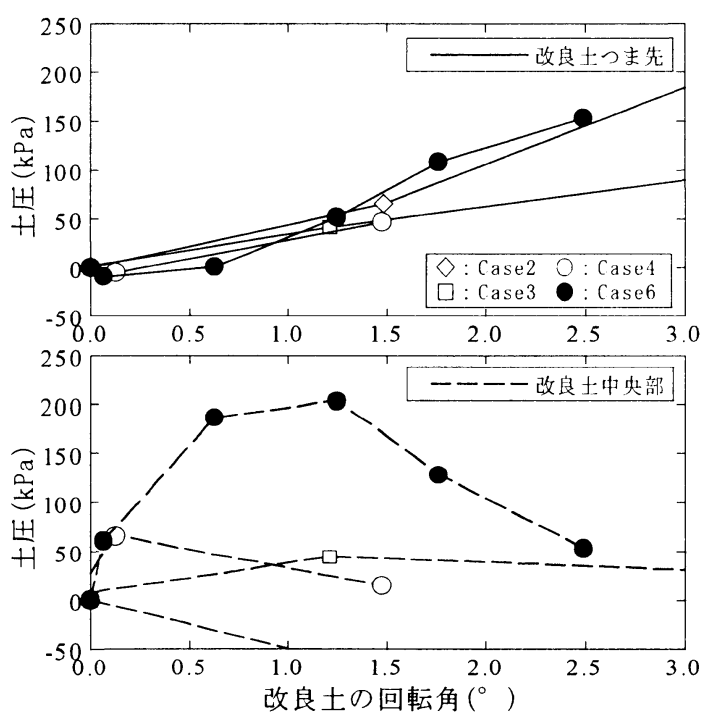

図-13 改良土壁回転角と土圧計測結果

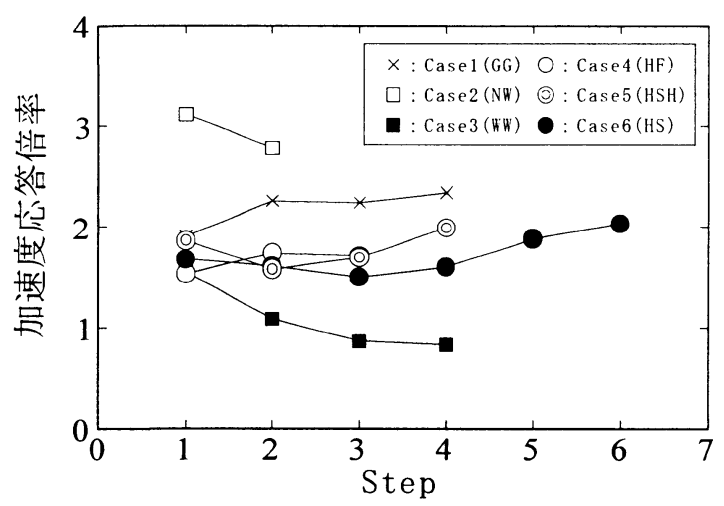

図-14 改良土地表面上の加速度応答倍率 


\section{e) 振動台実験終了後の状態}

図-15に各ケースの振動台実験終了後の応力（土 圧）状態および変形（壁面水平変位、盛土沈下量）状態 を示す。各ケースで入力した地震波エネルギーは異なる ものの、最も大きなエネルギーを入力したCase6の “短 繊維を混合した改良土とジオグリッドを組み合わせた補 強土壁” の壁面変位は小さく、土圧も卓越して大きな值 となっていないことから、地震時安定性に優れているこ とが確認できた。

\section{4. まとめ}

改良土とジオグリッドを組み合わせた補強土壁は、仮 に改良土に短繊維を混合しなくても、変形が小さく、地 震時安定性は高いことが明らかとなった。しかし、地震 時慣性力とジオグリッドによる抵抗力の 2 つの相反する 力により、改良土に引張りクラックが発生することが明 らかとなった。このクラックを抑制する方法として、今 回は、改良土に短䋐維を混合し、改良土の引張り抵抗力 を増加させることで、レベルா地震動に対してもより高 い而震性能をもつ構造となることが明らかとなった。

今後の課題として、計測した結果をさらに分析して、 ジオグリッドのひずみの計測を行い、地震時のメカニズ ムを把握するとともに、改良土のクラック抑制法を検証 してさらに本工法の耐震性の向上に努めていきたい。

\section{参考文献}

1) Tatsuoka, F., M. Tateyama and J. Koseki, Performance of soil retaining walls for railway embankments, in Special issue on Geotectnical Aspects of the January 17, 1995, Hyogoken-Nanbu Earthquake, Soil and Foundations, pp. 311-324, 1996.

2) 斉藤知哉、伊藤秀行 : 改良士とジオグリッドの摩擦特性、 第35回地盤工学研究発表会講演集,pp.1063-64,2000.6

3) 斉藤知哉、伊藤秀行 : 改良土とジオグリッドを組み合わせ た補強土壁、土木技術 vol.57, No.2,pp.82-89,2002.2

4) R. N. Taylor, S. Robson, R. J. Grant \& J. Kuwano, Image acquisition using an on-board film camera, Centrifuge 98, pp. 67-72, 1998.

5) 本多剛, 日比野常治, 高橋章浩, 桑野二郎: 砂質土中の浅い卜 ンネルの遠心模型実験 -地盤内の変形メカニズム-, 第35回地 盤工学研究発表会講演集,pp. 2061-2062,2000.

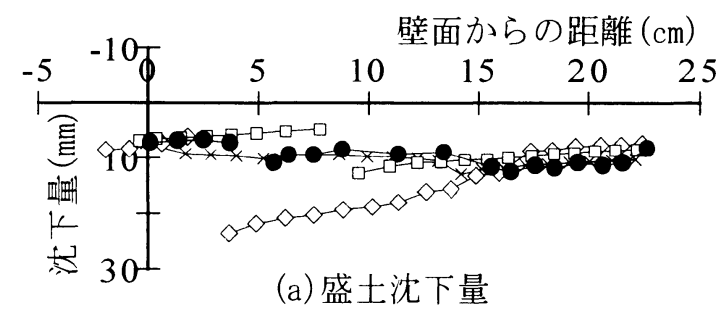

壁面変位量 $(\mathrm{mm})$ 改良土orパ 视に作用する土圧 30
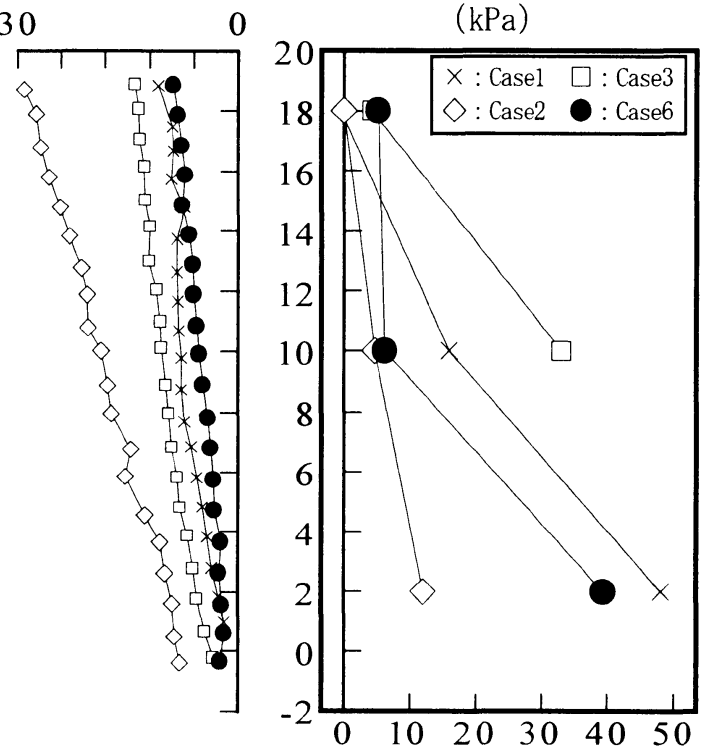

(b) 壁面変位量

(c) 水平土圧

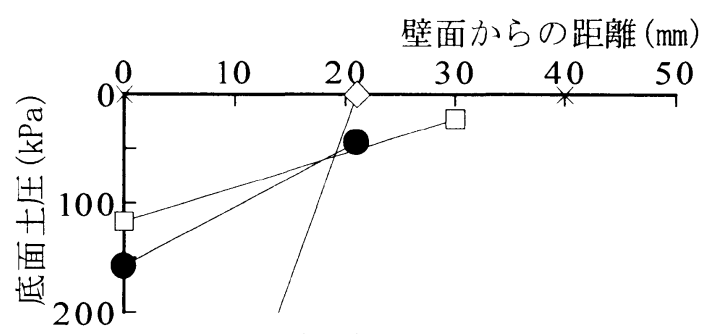

(d) 底面土圧

\section{図-15 振動台実験終了後の状態}

6) J. Takemura, A. Takahashi \& Y. Aoki, Development of horizontal-vertical 2D shaker in a centrifuge, Physical modeling in geotechnics -ICPMG 02, pp. 163-168, 2002.

\section{CENTRIFUGE SHAKING TABLE TEST \\ ON THE GEOGRID-REINFORCED SOIL WALL COMBINED WITH SOIL CEMENT}

\section{Tomoya SAITO, Hideyuki ITO, Jiro KUWANO and Jun IZAWA}

A new type geogrid-reinforced soil wall combined with soil cement was developed recently. Centrifuge shaking table tests were carried out to verify the seismic stability of this wall. Deformation was much smaller than those of the conventional geogrid-reinforced soil walls or the soil cement walls. Tension crack was induced at the top of the soil cement wall by the effect of inertia force induced in the soil cement wall. But the generation of tension crack was protected by mixing the short fibers in the soil cement and the reinforced soil wall showed very high seismic stability. 